Gus was welli-iked and a respected scholar and teacher. He deeply cared for his students and gave extraordinarily of his time to their intellectual nurturing and development. He contributed greatly to the department and faculty as chairperson of the political science department, member on faculty committees, and president of the Faculty Senate for two years. $\mathrm{He}$ was always willing to discuss research ideas and teaching methods with his colleagues.

Gus was also a humanitarian, deeply committed to bringing about social change for the betterment of humankind. Gus was a most valued colleague, friend, church member, and pillar of his community.

Gus was a political scientist who believed in the "crossover" of political science theory to practice. He not only instilled in his students participation in politics but he immersed himself in the game of politics. He was campaign manager several times for former Congressman Parren J. Mitchell, and he unsuccessfully ran for Congress himself in 1986 when Congressman Mitchell retired. He was also, for many years, election and political analyst on local Baltimore TV news and other programs.

Gus was a man of great integrity, loyalty, and charisma. We mourned his passing, and he will be deeply missed.

$$
\begin{array}{r}
\text { C. Vernon Gray } \\
\text { Michael Kamara } \\
\text { Morgan State University }
\end{array}
$$

\section{Chong-lk Eugene Kim}

Chong-lk Eugene Kim died on September 17, 1988, following a lengthy illness. After attending Seoul National University from 1947 to 1949, he enrolled in King College, Bristol, Tennessee, where he earned the B.A. degree in 1952. He received the M.A. degree from Vanderbilt University in 1954 and the Ph.D. degree from Stanford University in 1958. In 1960 he took his first full-time teaching position at Black Hills Teachers College, Spearfish, South Dakota. In the next year he came to
Western Michigan University, where he served for 27 years.

Eugene Kim's record of scholarship and service to the profession and the university was remarkable. In 1963 he founded Korea Research and Publication, which published seven monographs. He authored or coauthored or edited II books, published over 60 articles in books, conference proceedings, or professional journals, and presented over 40 papers at professional conferences. He received many research grants from his university and external agencies, sat on the board of editors of a number of professional journals, helped organize a large number of conferences at Western Michigan University and other universities in the United States and Korea, and participated with other internationally known scholars in a continuing dialogue on military studies and Korean affairs.

He traveled extensively in the Far East, often at his own expense, and was the leader of a network of scholars who eventually were organized into the Association of Korean Political Scientists in North America. He became president of that organization and received a leadership citation from it.

Along with his total devotion to scholarship, Gene was strongly committed to Western Michigan University, taking part in many committees and task forces. Most recently, as chair of the Asian Studies Committee, he organized the first Asian Forum, and coedited its proceedings, Changing Asia. He contributed a paper to the second forum despite his illness. He was very much interested in campus planning, promoting campus beautification, the expansion of the library, the establishment of a research institute and an office for regional development.

In 1981, Gene Kim was one of a group of six Korean scholars who were invited to visit North Korea. Although he was interested in advancing the cause of Korean reunification, his assessment of the prospects for reunification and his analysis of North Korea's proposals, like his other writings, always rested on a realistic foundation. He believed it was necessary to study North Korea firsthand as the best 
way to promote mutual understanding and achieve a lasting peace in the Korean peninsula.

Like a number of other professors in the various departments and colleges of the University, he helped to establish the international reputation of Western Michigan University. A separate collection consisting of his personal library, his publications, and other works on Korea, Asia, military studies and political development will be established in Waldo Library at Western Michigan University.

In 1984 Gene Kim was named Distinguished Faculty Scholar at Western Michigan University. This is how many will remember him, but his close friends and colleagues will also remember his good humor, ready smile, and generosity of spirit and good will.

Ernest E. Rossi

Western Michigan University

\section{James Clay Thompson}

James Clay Thompson, associate professor of political science at the University of North Carolina at Greensboro, died unexpectedly on January 15, 1989, in Greensboro. He was 45 years old.

James Clay Thompson was a teacher, a scholar, and a practitioner. He was born in Illinois on October 20, 1943. He received his B.A. in political science from the University of Wisconsin in 1965. He then spent several years as an intelligence research analyst in the Department of Defense, where his experience was later to form the basis for his Rolling Thunder: Understanding Policy and Program Failure, an analysis of the U.S. bombing campaign against North Vietnam between 1961 and 1968. In his review of this seminal work, Seymour Hersh called it "an honest inside account of the failure of one of the most ambitious bombing campaigns of the Vietnam War that also makes clear why the American military inevitably repeats its failures."

Jim joined the Department of Political Science at Vanderbilt University in 1973. He received his Ph.D. from the University of Michigan in 1975, and, in 1976, joined the Department of Political Science at the University of North Carolina at Greensboro.

In 1979 Jim returned to the Department of Defense for two years, where he served as special assistant for policy in the European and NATO Affairs branch of the Office of the Assistant Secretary of Defense, International Security Affairs. The major intellectual product of his second sojourn into the government was Defense Facts of Life, an incisive study of the defense procurement process that documents the inefficiencies in military procurement. The inability of the military and defense officials to "get it right" was a theme running throughout lim Thompson's work. He was also the co-author (with Richard F. Vidmer) of Administrative Science and Politics in the U.S. and the U.S.S.R:

Jim was as comfortable in the Pentagon and on Capitol Hill as he was in the classroom. Jim genuinely liked people and enjoyed dealing with them in many different environments. He was an 'in-andouter" who knew how to bring the lessons of his Washington experience into the classroom. But he was also a rigorous political scientist who applied organizational and behavioral theory to understanding the American political system.

I first met jim Thompson in September 1973, when we both joined the political science faculty at Vanderbilt University. Jim had just left a graduate program at the University of Michigan and I had just finished at Ohio State. That fall, and nearly every fall in the fifteen years since, jim and I placed a friendly wager (lunch) on the outcome of the Ohio State-Michigan football game. Even after we each departed Vanderbilt for other institutions, Jim kept in touch, and I could count on a telephone call every year at half-time during the Ohio State-Michigan game. The game and the wager weren't the important things; the communication was. Jim was like that, someone who made friends easily, remembered, and kept in touch.

I last saw Jim in Atlanta in September 1987, during a meeting of the Section on Military Studies of the International Studies Association. Jim had suffered serious health problems in recent years, but 